\title{
KOMUNIKASI MATEMATISPESERTA DIDIK DITINJAU BERDASARKAN KEMAMPUAN PENALARAN MATEMATIS DI KELAS XI MIA 5 SMAN 1 KEBOMAS
}

\author{
Olivia Maghfiroh, Sarwo Edy, Midjan. \\ Universitas Muhammadiyah Gresik \\ e-mail:aivilo.maghfiroh@gmail.com \\ Universitas Muhammadiyah Gresik \\ e-mail: sarwoumg@gmail.com \\ Universitas Muhammadiyah Gresik \\ e-mail:m.midjan@yahoo.com
}

\begin{abstract}
ABSTRAK
Kemampuan komunikasi dan penalaran matematis merupakan dua hal yang penting dalam pembelajaran matematika. Komunikasi matematis adalah kemampuan peserta didik dalam mengungkapkan ide atau gagasan secara tertulis melalui gambar, diagram, atau benda nyata dengan menggunakan bahasa, simbol, gambar, dll. Tujuan dari penelitian ini adalah untuk mendeskripsikan komunikasi matematis tulis peserta didik ditinjau berdasarkan tingkat kemampuan penalaran matematis tinggi, sedang, dan rendah.

Jenis penelitian yang digunakan adalah deskriptif. Subjek penelitian yang digunakan adalah 6 peserta didik kelas XI MIA 5 SMAN 1 Kebomas tahun pelajaran 2016/2017. Pengumpulan data menggunakan tes kemampuan penalaran matematis dan tes komunikasi matematis. Tes kemampuan penalaran matematis ini diberikan terlebih dahulu untuk menentukan kategori tingkat kemampuan penalaran matematisnya.

Hasil dalam penelitian ini menunjukkan bahwa komunikasi matematis tulis peserta didik yang memiliki kemampuan penalaran matematis tinggi dalam menyelesaikan persoalan aplikasi integral pada daerah luas subjek HM adalah subjek dapat memberikan ide dengan menuliskan langkah-langkahnya menggunakan konsep aplikasi integral pada daerah luas secara runtut, jelas, dan sistematis sehingga menghasilkan jawaban yang benar tetapi pada aspek menggambar subjek dapat menggambar kedua kurva yang diketahui dan tidak memperhatikan titik perpotongannya. Sedangkan pada subjek MAH dapat menuliskan ide yang sama dengan subjek HM tetapi subjek salah memfaktorkan batasnya. Peserta didik dengan kemampuan penalaran matematis sedang pada subjek MDR juga dapat menuliskan ide yang sama dengan subjek HM tetapi terdapat kesalahan dalam menguadratkan salah satu sukunya. Sedangkan pada subjek RA ide yang dituliskan sama dengan subjek HM tetapi terdapat kesalahan dalam menyederhanakan pecahan di akhir jawabannya. Peserta didik dengan kemampuan penalaran matematis rendah pada subjek MTFW adalah subjek menuliskan konsep tidak sesuai dengan aplikasi integral tetapi menggunakan konsep lain yaitu rumus volume balok. Sedangkan pada subjek NALR, subjek menuliskan langkah-langkahnya menggunakan konsep integral namun terdapat banyak kesalahan dalam menuliskan model matematikanya.
\end{abstract}

Kata kunci: Kemampuan Penalaran Matematis, Komunikasi Matematis 


\begin{abstract}
Mathematical communication is the ability of learners to express ideas or ideas in writing through drawings, diagrams, or real objects using language, symbols, images, graphics, and others in solving mathematical problems. Communication skills and mathematical reasoning are two things that are important in the study of mathematics. The purpose of this research is to describe the mathematical communication learners reviewed based on the level of mathematical reasoning abilities of high, medium, and low.

This type of research is descriptive. The subjects of the research is 6 students in class XI MIA 5 SMAN 1 Kebomas 2016/2017 school year. Collecting data using mathematical reasoning ability tests and test mathematical communication. This mathematical reasoning ability tests given beforehand to determine each category of mathematical reasoning ability level.

The results in this study show that written mathematical communication learners who have the capability of mathematical reasoning high in resolving application issues integral to the wide area of HM subject is the subject can give an idea to write down the steps using the concept of applications integral to a wide area in a coherent, clear and systematically so as to produce the correct answer but in the aspect of drawing subject can draw the two curves are known and do not pay attention to the point of intersection. While on the MAH subject can write the same idea as with HM subject but subject factoring limit. Learners with mathematical reasoning medium of MDR subject can also write the same idea with HM subject but there are errors in squaring one tribe. While on the RA subject same idea with HM subject but there are errors in simplifying fractions in the final answer. Learners with low mathematical reasoning skills on the MTFW subject is write a concept incompatible with the integral application but use another concept that formula beam volume. While on the NALR subject, the subject write the steps using integral concept but there are many mistakes in writing down the mathematical models.
\end{abstract}

Keywords: Mathematical Reasoning Ability, Mathematical Communications 


\section{PENDAHULUAN}

Komunikasi merupakan bagian yang penting dalam dunia pendidikan khususnya pada mata pelajaran matematika. Hal ini tertuang dalam Permendiknas No. 22 Tahun 2006 dimana tujuan dari pembelajaran matematika pada poin ke empat adalah agar peserta didik memiliki kemampuan untuk mengomunikasikan gagasan dengan simbol, tabel, diagram, atau media lain untuk memperjelas keadaan atau masalah. Tujuan tersebut juga sejalan dengan NCTM (National Council of Theachers of Mathemathics) yang menetapkan standar proses (the process standards) dalam pembelajaran matematika salah satunya yaitu kemampuan berkomunikasi (NCTM, 2000: 29).

Apabila dicermati dalam tujuan mata pelajaran matematika yang ditetapkan dalam Permendiknas No. 22 Tahun 2006 dan standar matematika dalam NCTM (2000) tersebut terlihat bahwa kurikulum yang disusun sudah memperhatikan aspek kemampuan berkomunikasi. National Council of Theachers of Mathemathics mendefinisikan bahwa komunikasi matematis adalah bagian yang esensial dari matematika dan pembelajaran matematika, karena komunikasi merupakan cara untuk menyalurkan ide-ide dan merefleksikan pemahaman tentang matematika (NCTM, 2000: 60).

Kemampuan lain dalam pembelajaran matematika yang tertulis dalam tujuan pembelajaran matematika dan standar proses yang ditetapkan oleh NCTM adalah kemampuan penalaran. Menurut Keraf (1982: 5) penalaran adalah suatu proses berfikir yang menghubunghubungkan fakta-fakta atau evidensievidensi yang diketahui menuju kepada suatu kesimpulan. Sedangkan menurut Offirstson (2014: 41) menjelaskan bahwa penalaran matematis adalah kemampuan berfikir dalam melihat dan menganalisis fenomena yang muncul dan kemudian disusun suatu konjektur yang dapat digunakan dalam penarikan kesimpulan.

Kemampuan penalaran dan komunikasi matematis merupakan dua hal yang tidak dapat dipisahkan. Menurut Amir (2014: 32) dalam penelitiannya yang mengatakan bahwa jika peserta didik dapat mengomunikasikan idenya berarti kemampuan penalarannya sudah dibentuk. Menurut Ainun, dkk (2015: 72) Penalaran matematis merupakan suatu kebiasaan otak yang apabila dikembangkan dengan baik dan konsisten akan memudahkan dalam mengomunikasikan matematika baik secara tertulis maupun lisan. Menuangkan gagasan atau ide-ide matematika bukanlah hal yang mudah, karena diperlukan kecermatan dan daya nalar yang 
baik(2015: 72). Brodie (2010: 7) juga mengungkapkan bahwa ketika kita bernalar, berarti kita mengembangkan pemikiran atau argument atau untuk mengintegrasikan sejumlah ide menjadi satu kesatuan yang koheren.

Pertanyaan dalam peneltian ini adalah: a) Bagaimana komunikasi matematis tulis peserta didik ditinjau berdasarkan kemampuan penalaran matematis tinggi di kelas XI MIA 5 SMAN 1 Kebomas?, b) Bagaimana komunikasi matematis tulis peserta didik ditinjau berdasarkan kemampuan penalaran matematis sedang di kelas XI MIA 5 SMAN 1 Kebomas?, dan c)
Bagaimana komunikasi matematis tulis peserta didik ditinjau berdasarkan kemampuan penalaran matematis rendah di kelas XI MIA 5 SMAN 1 Kebomas?

\section{METODE PENELITIAN}

Jenis penelitian yang digunakan dalam penelitian ini adalah penelitian deskriptif. Subjek penelitian yang digunakan adalah 6 peserta didik kelas XI MIA 5 SMAN 1 Kebomas tahun pelajaran 2016/2017. Subjek penelitian dipilih berdasarkan tingkat kemampuan penalaran matematis tinggi, sedang, dan rendah. Untuk pengkategorian berdasarkan Kemendikbud No. 81A Tahun 2013 yaitu:

Tabel 1 Kriteria Tingkat Kemampuan Penalaran Matematis

\begin{tabular}{|c|c|}
\hline Nilai & $\begin{array}{c}\text { Kategori Penalaran } \\
\text { Matematis }\end{array}$ \\
\hline $2.66 \leq x \leq 4$ & Tinggi \\
\hline $1.66 \leq x \leq 2.65$ & Sedang \\
\hline$x \leq 1.65$ & Rendah \\
\hline
\end{tabular}

Instrumen yang digunakan dalam penelitian ini adalah 1) Soal komunikasi matematis yang terdiri dari 15 soal yang diadopsi dari ETS. Soal-soal penalaran matematis tersebut sudah pernah diujicobakan pada peserta didik dan dinyatakan sebagai soal yang valid sehingga tidak perlu divalidasi dan diujicobakan lagi. Dari 15 soal yang diambil, terdiri dari tiga bagian yaitu 3 soal membandingkan dengan memilih satu jawaban benar, 7 soal pilihan ganda dengan memilih satu jawaban benar, dan 5 soal uraian. Soal tes kemampuan penalaran matematis ini digunakan untuk menentukan kategori tingkat kemampuan penalaran matematisnya.2) Soal komunikasi matematis yang terdiri dari satu soal uraian dan disesuaikan dengan indikator komunikasi matematis. Soal komunikasi matematis ini sebelumnya telah divalidasi oleh 2 ahli yaitu dosen $\mathrm{S} 1$ 
pendidikan matematika FKIP UMG dan guru matematika SMAN 1 Kebomas dan dinyatakan sebagai soal yang valid.

Analisis data yang digunakan pada penelitian ini adalah analisis data secara deskriptif dalam bentuk uraian (kata-kata) dengan berpedoman pada kriteria penilaian dan indikator kemampuan komunikasi matematis tulis.

HASIL DAN ANALISIS DATA

Hasil Tes Kemampuan Penalaran Matematis

Berdasarkan hasil tes kemampuan penalaran matematis didapatkan data sebagai berikut:

Tabel 2 Hasil Tes Kemampuan Penalaran Matematis

\begin{tabular}{|c|c|}
\hline Jumlah & Kategori Tingkat Penalaran Matematis \\
\hline 2 & Tinggi \\
\hline 13 & Sedang \\
\hline 19 & Rendah \\
\hline
\end{tabular}

Dari hasil tes kemampuan penalaran matematis dipilih 2 subjek dari masing-masing kategori diantaranya:

1. Kategori penalaran matematis tinggi yaitu subjek HM (2.8) dan subjek MAH (2.68)

2. Kategori penalaran matematis sedang yaitu subjek MDR (2.2) dan subjek RA (2.12)

3. Kategori penalaran matematis rendah yaitu subjek MTFW $(0,72)$ dan subjek NALR (0.6)

Hasil Komunikasi Matematis Tulis oleh Peserta Didik dengan Kemampuan Penalaran Matematis Tinggi

Hasil analisis data menunjukkan bahwa komunikasi matematis tulis peserta didik yang memiliki kemampuan penalaran matematis tinggi pada subjek HM adalah: 1) Subjek dapat menuliskan ide-idenya dengan menggunakan bahasa, simbol, atau istilah-istilah dalam matematika namun terdapat kekurangan dalam penulisan simbol pada sumbu koordinat $x, y$ dan tidak konsisten dalam menuliskan simbol pada model matematikanya dimana simbol yang ditulis adalah $y_{\text {atas }}$ dan $y_{\text {bawah }}$, 2) Subjek dapat membuat gambar tetapi gambar yang dibuat salah tidak sesuai letak titik perpotongan pada sumbu koordinat, titik potong pada sumbu koordinatnya terpacu pada batas luas daerah tetapi masih mengandung konsep tentang kedua kurva namun masih mengandung pemahaman konsep tentang kedua kurva. Subjek langsung mengetahui letak kurva yang atas dan yang bawah, 3) Subjek dapat menuliskan apa yang diketahui, ditanya dan langkah-langkah dalam menemukan 
jawaban secara terstruktur, runtut, dan jelas, 4) Subjek dapat membuat model matematika secara tepat, 5) Subjek dapat memberikan solusi akhir dengan benar, namun tidak terdapat satuan, dan kalimat dalam kesimpulan sudah tepat.

Pada subjek MAH, komunikasi matematis tulis yang dimiliki adalah: 1) Subjek dapat menuliskan ide-idenya dengan menggunakan bahasa, simbol, atau istilah-istilah dalam matematika namun terdapat kekurangan penulisan simbol pada sumbu koordinat $x, y$ dan pada model matematikanya tidak memberikan simbol “dx", 2) Subjek dapat membuat gambar tetapi gambar yang dibuat salah, tidakmemperhatikan titik potong kedua kurva dan salah dalam meletakkan keterangan fungsi pada kedua kurva tersebut namun masih mengandung pemahaman konsep tentang kedua kurva. Subjek langsung mengetahui letak kurva yang atas dan yang bawah, 3) Subjek dapat menuliskan apa yang diketahui, ditanya dan langkah-langkah dalam menemukan jawaban sudah memenuhi konsep tetapi dalam melakukan pemfaktorannya salah dalam meletakkan tanda operasi “+” dan “_“" sehingga batas yang didapatkan salah dan salah dalam mengintegralkan salah satu sukunya sehingga mempengaruhi hasil jawaban akhir, 4) Subjek dapat menuliskan model matematika, namun ada satu tahap yang terlewatkan, 5) Subjek tidak dapat memberikan solusi akhir dengan benar karena dari awal perhitungan batas yang diberikan salah, tidak terdapat satuan, dan kalimat dalam kesimpulan hampir tepat.

\section{Hasil Komunikasi Matematis Tulis oleh Peserta Didik dengan Kemampuan Penalaran Matematis Sedang}

Komunikasi matematis tulis peserta didik yang memiliki kemampuan penalaran matematis sedang pada subjek MDR adalah: 1) Subjek dapat menuliskan ide-idenya dengan menggunakan bahasa, simbol, atau istilah-istilah dalam matematika namun terdapat sedikit kekurangan penulisan pada simbol luas perkebunan dan penulisan pada model matematika tidak konsisten seperti yang dituliskan di persamaan awal dan tidak menuliskan simbol “ $d x$ ” 2) Subjek dapat membuat gambar dengan tepat dan benar sesuai pemahaman konsep tentang kedua kurva dengan cara memasukkan nilai $x$ ke dalam persamaan kedua kurva sehingga diketahui titik potongnya, 3) Subjek dapat menuliskan apa yang diketahui, ditanya, dan langkah-langkah dalam menemukan jawaban sudah memenuhi konsep tetapi dalam perhitungannya terdapat kesalahan yaitu salah dalam menguadratkan salah satu sukunya, 4) Subjek dapat menuliskan model matematika tetapi tidak menuliskan simbol " $d x "$, 5) Subjek tidak dapat memberikan solusi akhir dengan benar 
karena terdapat satu langkah yang perhitungannya salah, tidak terdapat satuan, dan kalimat dalam kesimpulan sudah tepat namun jawabannya yang salah.

Pada subjek RA, komunikasi matematis tulis yang dimiliki adalah: 1) Subjek dapat menuliskan ide-idenya dengan menggunakan bahasa, simbol, atau istilah-istilah dalam matematika namun terdapat sedikit kekurangan penulisan simbol pada sumbu koordinat $x, y$ dan pada model matematika tidak memberikan simbol " $d x$ ", 2) Subjek dapat membuat gambar dengan tepat namun tidak menuliskan langkah-langkah dalam menggambar tetapi dengan mencoba-coba sampai 3 kali sehingga dihasilkan gambar yang benar, 3) Subjek dapat menuliskan apa yang diketahui, ditanya dan langkahlangkah dalam menemukan jawaban sudah runtut meskipun ada satu tahap yang terlewatkan dan jawabannya sudah hampir benar namun terdapat kesalahan dalam menyederhanakan pecahan, 4) Subjek dapat menuliskan model matematika, namun ada satu tahap yang terlewatkan, 5) Subjek dapat memberikan solusi akhir yang hampir benar, tidak terdapat satuan, dan kalimat dalam kesimpulan sudah tepat.

Hasil Komunikasi Matematis Tulis oleh

Peserta Didik dengan Kemampuan

Penalaran Matematis Rendah

Komunikasi matematis tulis peserta didik yang memiliki kemampuan penalaran matematis rendahpada subjek MTFW adalah: 1) Subjek dalam menuliskan ide-idenya dengan menggunakan bahasa, simbol, atau istilahistilah dalam matematika terdapat kekurangan dan kesalahan penulisan simbol luas perkebunan, 2) Subjek dapat membuat gambar tetapi gambar yang dibuat salah tidak memperhatikan letak titik perpotongan kedua kurva dengan sumbu koordinat $x, y$ namun masih mengandung sedikit pemahaman konsep tentang kedua kurva, 3) Subjek dapat menuliskan apa yang diketahui, ditanya dan langkah-langkah dalam menemukan jawaban tidak memenuhi konsep aplikasi integral pada daerah luas tetapi dengan menggunakan rumus volume balok sehingga dalam perhitungannya salah, 4) Subjek tidak menuliskan model matematika yang sebenarnya karena konsep yang digunakan salah, 5) Subjek tidak dapat memberikan solusi akhir dengan benar karena dari awal menghitung luas konsep salah, tidak terdapat satuan, dan kalimat dalam kesimpulan tepat.

Pada subjek NALR, komunikasi matematis tulis yang dimiliki adalah: 1) Subjek dapat menuliskan ide-idenya dengan menggunakan bahasa, simbol, atau istilah-istilah dalam matematika namun terdapat banyak kekurangan penulisan simbol matematika pada gambar sumbu 
koordinatnya. Selain itu, pada langkah mencari luas setelah diintegralkan tetap masih ditulis simbol integralnya dan tidak terdapat simbol " $d x ", 2)$ Subjek dapat membuat gambar tetapi gambar yang dibuat salah, titik perpotongan kedua kurva tidak sesuai dengan sumbu koordinatnya, 3) Subjek dapat menuliskan apa yang diketahui, ditanya, dan langkah-langkah yang dituliskan terdapat banyak kesalahan karena konsep yang digunakan adalah aplikasi integral tetapi terdapat kesalahan dalam menuliskan model matematikanya, 4) Subjek salah dalam menuliskan model matematika, 5) Subjek tidak dapat memberikan solusi akhir dengan benar karena dari awal terdapat kesalahan konsep, tidak terdapat satuan, dan kalimat dalam kesimpulan tepat.

\section{KESIMPULAN}

Berdasarkan uraian dari hasil analisis data kemampuan komunikasi matematis tulis, dapat disimulkan bahwa:

1. Kemampuan komunikasi matematis tulis peserta didik yang memiliki kemampuan penalaran matematis tinggi pada subjek HM dalam menyelesaikan persoalan aplikasi integral pada daerah luas adalah subjek dapat memberikan ide dengan menuliskan langkahlangkahnya menggunakan konsep aplikasi integral pada daerah luas secara runtut, jelas, dan sistematis sehingga dapat menghasilkan jawaban yang benar tetapi pada aspek menggambar subjek dapat menggambar kedua kurva yang diketahui. Subjek dapat mengetahui secara langsung letak kurva yang atas dan bawah tetapi letak titik perpotongan dengan sumbu koordinat $x$ dan $y$ adalah batas dari kedua kurva dan pada aspek menggunakan kosa kata/bahasa, notasi subjek kurang menuliskan simbol pada sumbu koordinat $x$ dan $y$ dan tidak konsisten dalam penulisan simbol pada model matematikanya serta tidak memberikan satuan luas pada akhir jawabannya. Sedangkan pada subjek MAH dapat memberikan ide dengan menuliskan langkah-langkahnya menggunakan konsep aplikasi integral pada daerah luas tetapi dalam mencari batas luas subjek salah memfaktorkannya dan terdapat kesalahan dalam mengintegralkan salah satu sukunya sehingga mempengaruhi hasil akhirnya. Pada aspek menggambar subjek dapat membuat gambar tetapi gambar yang dibuat tidak memperhatikan letak titik perpotongan kedua kurva dan subjek langsung mengetahui letak kurva yang atas dan yang bawah. Pada aspek menggunakan kosa kata/bahasa, notasi subjek kurang menuliskan simbol pada sumbu koordinat $x$ dan $y$, pada model matematikanya tidak memberikan 
simbol " $d x$ " serta tidak memberikan satuan luas pada akhir jawabannya.

2. Kemampuan komunikasi matematis tulis peserta didik yang memiliki kemampuan penalaran matematis sedang pada subjek MDR dalam menyelesaikan persoalan aplikasi integral pada daerah luas adalah subjek dapat memberikan ide dengan menuliskan langkah-langkahnya menggunakan konsep aplikasi integral pada daerah luas secara runtut, jelas, dan sistematis tetapi terdapat kesalahan dalam menguadratkan salah satu sukunya sehingga mempengaruhi hasil akhirnya dan pada aspek menggambar subjek dapat membuat gambar dengan tepat dan benar sesuai pemahaman konsep tentang kedua kurva dengan cara memasukkan nilai $x$ ke dalam persamaan kedua kurva sehingga diketahui titik potongnya. Pada aspek menggunakan kosa kata/bahasa, notasi subjek terdapat sedikit kekurangan yaitu penulisan pada model matematika tidak konsisten seperti yang dituliskan di persamaan awal dan tidak menuliskan simbol " $d x$ " serta tidak terdapat satuan luas di akhir jawaban.Sedangkan pada subjek RA dapat memberikan ide dengan menuliskan langkah-langkahnya menggunakan konsep aplikasi integral pada daerah luas secara runtut, jelas, dan sistematis tetapi terdapat kesalahan dalam menyederhanakan pecahan di akhir jawabannya dan pada aspek membuat gambar subjek dapat membuat gambar dengan cara cobacoba sehingga dihasilkan gambar yang benar. Pada aspek menggunakan kosa kata/bahasa, notasi subjek terdapat sedikit kekurangan penulisan letak sumbu koordinat $x, y$ dan pada model matematikanya tidak menuliskan simbol " $d x$ " serta tidak memberikan satuan luas pada akhir jawabannya.

3. Kemampuan komunikasi matematis tulis peserta didik yang memiliki kemampuan penalaran matematis rendah pada subjek MTFW dalam menyelesaikan persoalan aplikasi integral pada daerah luas adalah subjek menuliskan langkah-langkahnya tentang mencari luas tetapi konsep yang digunakan tidak sesuai dengan konsep aplikasi integral pada daerah luas namun menggunakan konsep lain yaitu dengan menggunakan rumus volume balok. Pada aspek menggambar peserta didik menggambar kedua kurva yang diketahui tetapi tidak memperhatikan letak titik perpotongan dengan kedua kurva. Pada aspek menggunakan kosa kata/bahasa, notasi peserta didik terdapat banyak kekurangan dalam penulisan simbol karena konsep yang digunakan tidak sesuai dengan konsep 
aplikasi integral pada daerah luas. Sedangkan pada subjek NALR, subjek menuliskan langkah-langkahnya tentang mencari luas tetapi konsep yang digunakan adalah konsep integral namun terdapat kesalahan dalam menuliskan model matematikanya. Pada aspek menggambar subjek menggambar kedua kurva yang diketahui tetapi tidak memperhatikan letak titik perpotongan dengan kedua kurva. Pada aspek menggunakan kosa kata/bahasa, notasi subjek namun terdapat banyak kekurangan penulisan simbol matematika pada gambar sumbu koordinatnya. Selain itu, pada langkah mencari luas setelah diintegralkan tetap masih ditulis simbol integralnya dan tidak terdapat simbol " $d x "$ serta tidak memberikan satuan luas di jawaban akhirnya.

\section{DAFTAR PUSTAKA}

Ainun, Nur, dkk. 2015. "Peningkatan Kemampuan Komunikasi dan Penalaran Matematis Siswa Madrasah Aliyah Melalui Model Pembelajaran Kooperatif Tipe Teams Games Tournament”. Jurnal Didaktik Matematika. ISSN: 2355-4185: hal 71 - 83

Amir, Almira. 2014. "Kemampuan Penalaran dan Komunikasi dalam Pembelajaran
Matematika”.Logaritma. Vol. II, No. 01: hal $18-33$

Ansari, Bansu I. 2016. Komunikasi Matematik, Strategi Berfikir dan Manajemen Belajar Konsep dan Aplikasi. Banda Aceh: Penerbit PENA

Brenner, Mary E. 1998. Development of Mathematical Communication in Problem Solving Groups By Language Minority Student. Billingual Research Journal, 22:2, 3 \& 4 Spring, Summer, \& Fall 1998.

http://cimm.ucr.ac.cr/ojs/index.ph p/eudoxus/article/viewFile/250/22

1 diakses pada tanggal 27 Februari 2017.

Brodie, Karin. 2010. Teaching Mathematical Reasoning in Secondary Classroom (Online). New York: Spinger.http://www.springer.com/ gp/book/9780387097411diakses pada tanggal 20 Februari 2017.

Clark, Karen K, dkk. 2005. Strategies for Building Mathematical Communication in the Middle School Classroom: Modeled in Professional Development, Implemented in the Classroom. CIMLE (Current Issues in The Middle Level Education) (2005)11(2), 1-12. 
ERB (Educational Record Bureau). 2011.

CTP 4 (Comprehensive Testing Program) Content Standard Manual. New York City.

ETS (Educational Testing Service). 2011. The Official Guide to the GRE Revised General Test. New York.

ETS (Educational Testing Service). 2012. Practice Book for the PaperBased GRE revised General Test Second Edition. United State.

Keraf, Gorys. 1982. Narasi dan Argumentasi Komposisi Lanjutan III. Jakarta: PT Gramedia Pustaka Utama.

NCTM. 2000. Principles and Standards for School Mathematics.Reston VA: USA. ISBN 0-873353-480-8
Offirstson, Topic. 2014. Aktivitas Pembelajaran Matematika Melalui Inkuiri Berbantuan Software Cinderella. Yogyakarta: CV Budi Utama.

Permendiknas. 2006. Standar Isi Mata Pelajaran Matematika SD/MI dan SMP/MTs (PermendiknasNo. 22 Tahun 2006). Jakarta: BSNP.

Rohana. 2015. Kemampuan Penalaran Matematis Mahasiswa Calon Guru Melalui Pembelajaran Reflektif. (online), Vol 4 No 1.http://ejournal.stkipsiliwangi.ac. id/index.php/infinity/article/view/ 76diakses pada tanggal 12 Januari 2017 